\title{
A KÉT VAGY TÖBB NYELVET BESZÉLŐ SZEMÉLYEK MEMÓRIARENDSZERE
}

\author{
POLONYI TÜNDE ÉVA
}

ELTE, Általános Pszichológiai Tanszék

ELTE, Pszichológia Doktori Iskola, Kognitív Program

E-mail: tutu@izabell.elte.hu; tundel@hotmail.com

\begin{abstract}
A két- és többnyelvüek információtárolása és -feldolgozása vitatott téma: egyes kutatók szerint ez olyan kognitív alrendszerek segitségével történik, amelyek tartalmazzák az emlékezeti képzeteket is és beszélt nyelveikkel állnak kapcsolatban, viszont funkcionálisan függetlenek egymástól (a függetlenség hipotézise); egy másik modell szerint (az egymástól való függés hipotézise) a különálló lingvisztikai rendszerek funkcionálisan kötödnek egy olyan közös fogalmi rendszerhez, ami egyben a megosztott memóriatároló is. Kísérletem célja az volt, hogy egyetlen vizsgálatban, különbözö bevésési stratégiákat és elöhivási feladatokat alkalmazva olyan teljesitménymintákat mérjek fel, amelyeket egyik vagy másik modell alátámasztására szoktak felhozni; ezenkivüll a fejlödési hipotézist is vizsgálom.

Magyar-román-angol háromnyelvüek vettek részt a vizsgálatban két csoportba osztva. Hipotézisem szerint az angolt nehézkesebben beszélők teljesitménye egy adatvezérlésü szókiegészitési feladatnál a függetlenégi hipotézist kell hogy alátámassza, azonban eredményeim azt mutatták, hogy az adatvezérlésü és fogalmi vezérlésü feldolgozás itt együtt jelentkezik; a szabad felidézési feladat eredményei a nyelvtól való függetlenség hipotézisét támasztották alá, a felismerési feladat eredményei pedig szintén a két típusú feldolgozás kombinációját mutatták. Az angolt folyékonyabban beszélő alanyok esetében nem találtam szignifikáns különbségeket a különböző bevésési stratégiák között, ami újabb bizonyitékot jelent KROLL és STEWART (1994) modellje mellett. A nehézkesebben beszélö háromnyelvüek tehát a lexikális és fogalmi közvetités kombinációját mutatták, és csak a gyakorlott beszélókre jellemzö a tiszta fogalmi közvetités. Általános közetkeztetésem az, hogy a leghasznosabb kutatási paradigma egy olyan transzferközpontú szemlélet lenne, amelyben a megórzési próbákon való teljesítmény olyan mértékben javul, amilyen mértékben a teszt által megkövetelt eljárások megismétlik a bevésési eljárásokat.
\end{abstract}

Kulcsszavak: háromnyelvüek, memóriarendszer, transzfer, fejlödési hipotézis, lexikális és fogalmi közvetítés 


\section{IRODALMI ÁTTEKINTÉS}

A kétnyelvűség nagyon elterjedt jelenség, gyakorlatilag a világ minden országában jelen van, minden korosztály és minden társadalmi kategória esetén megtalálható; egyes statisztikai felmérések szerint a világ népességének legalább fele két- vagy többnyelvü.

A mindennapi tapasztalat kétnyelvűnek nevezi azt az egyént, aki két különböző nyelvet nagyjából egyforma hatékonysággal beszél. SEGALOWITZ (1986) szerint viszont ez a meghatározás nem megfelelő, mivel így kizárjuk azokat, akik anyanyelvükön kívül más nyelven is képesek kommunikálni, ezért ő azokat a személyeket nevezi folyékonyan beszélő kétnyelvűeknek, akik minden általuk ismert nyelven egyenlő mértékben tudják kifejezni magukat, és folyékonyan is beszélik mindegyiket, még akkor is, ha rossz hangsúllyal, míg az egyszerű „kétnyelvü” elnevezés a második nyelven való gyakorlottság fokától függetlenül használatos.

Jelen dolgozatban a kétnyelvüség fogalmát a lehető legszélesebb értelemben használom, beleértve minden egyént, aki aktívan használ vagy próbál használni több mint egy nyelvet, még akkor is, ha nem beszéli ezeket teljesen folyékonyan. Közvetítésnek azt a folyamatot tekintem, amely révén fogalmak közreműködésével megértünk egy bizonyos nyelvű szót.

Melyik nyelvén gondolkozik egy kétnyelvű, mindig az anyanyelvén? Vagy képes az általa ismert második vagy harmadik nyelven is gondolkozni, amikor olyan anyaggal találkozik, amely az illető nyelven van megfogalmazva? Esetleg az az eset áll fenn, hogy a gondolkodás nem egy bizonyos nyelven folyik, hanem inkább elvont, nem nyelvspecifikus fogalmi formában? Vajon az a képességünk, hogy két vagy három nyelven értünk és beszélünk, azt jelenti, hogy egy embernek két vagy több mód áll a rendelkezésére az emlékezés, megismerés és gondolkodás céljából? Vagy ezek a nyelvi rendszerek funkcionálisan kötődnek egy közös kognitív vagy fogalmi rendszerhez?

Az ellentétes állásfoglalások különböző neveket viselnek: függetlenség, illetve egymástól való függőség, nyelvtől függő, illetve nyelvtől független elmélet. A nyelvtől való függetlenség elmélet azt hirdeti, hogy a kétnyelvüek két olyan, funkcionálisan egymástól független kognitív alrendszerrel rendelkeznek, amelyek tartalmazzák a memóriakészleteket is és a két ismert nyelvvel állnak kapcsolatban. Az egymástól való függés hipotézise szerint viszont a különálló nyelvi rendszerek funkcionálisan kötöttek egy közös fogalmi rendszerhez, ami egyben megosztott memóriát is jelent. E modell szerint a kétnyelvủek a szavak fogalmi jelentését egy olyan nyelvfeletti kódban jelenítik meg, amely független attól a nyelvtől, amelyen a szavak megjelentek. A függetlenségi modell viszont azt mondja ki, hogy lényegileg különálló, nyelvspecifikus kódok léteznek, asszociatív kapcsolatokkal a két rendszer egymásnak megfelelő fogalmai között.

$\mathrm{Az}$ ellentétes nézeteket és empirikus bizonyítékaikat részletesen tárgyalták (Kolers, 1963; Paivio, Desrochers, 1980; Kolers, GonZales, 1980; POTter, So, VON ECKHARDT, FELDMAN, 1984; SNODGRASS, 1984; DuRDUNOGLU, Roediger, 1987; DE Groot, 1992b; Dufour, Kroll, 1995; Sholl, SANKARANARAYANAN, KROLL, 1995). A függetlenség álláspontját a következő 
megfigyelések támasztják alá: a) a kétnyelvúek szóasszociációi a két nyelven egymásnak megfelelő szavakra jobban különböznek egymástól, mint ahogy azt az egymástól való kölcsönös függés elmélete hirdeti; $b$ ) az egyik nyelvről egy másikra való áttérés néhány feladat esetén plusz időt igényel; $c$ ) a kétnyelvűek általában pontosabban emlékeznek arra, hogy egy szó egy kevert nyelvủ listáról milyen nyelven volt bemutatva, mint ahogy ezt a véletlen diktálná; $d$ ) az előfeszítési hatások néha nem vivődnek át egyik nyelvről a másikra.

A következő eredményeket értelmezték úgy, hogy inkább az egymástól való függés vagy a megosztott rendszer felfogással állnak összhangban: $a$ ) a kétnyelvűek túl gyakran adnak hasonló asszociációkat a különböző nyelveken megfogalmazott szavakra ahhoz, hogy kizárólagosan a függetlenségi állásfoglalást tartsuk igaznak; b) pozitív transzferhatásokat lehet megfigyelni egy sor verbális tanulási feladatnál akkor, amikor a szólistákat a kétnyelvűeknek egyik nyelvről a másikra váltják át; $c$ ) kétnyelvü listák szabad felidézésekor a kétnyelvűek a tételeket nem a nyelv, hanem a fogalmi kategória szerint csoportosítják; és $d$ ) a fordítási és képmegnevezési feladatok reakcióidői hasonlóak, azt sugallva, hogy mindkét feladatot ugyanaz az amodális fogalmi rendszer közvetíti.

Általában véve úgy tartják, hogy a függőségi elméletet támasztják alá azok az emlékezeti vizsgálatok, amelyekben a szavak két nyelven való bemutatása ugyanolyan hatással van a teljesítményre, mint amikor a bemutatás mindkét alkalommal ugyanazon a nyelven történik: ha létezik egy közös kód, akkor a szó értelmének a bemutatás nyelvétől függetlenül kell a teljesítményt befolyásolnia.

Egy szabad felidézési kísérletben KolERs és GONZALES (1980) spanyol és angol szavakat adtak kétnyelvủ személyeiknek. A tételeket egyszer, kétszer vagy háromszor mutatták be és az ismétlések vagy az eredeti bemutatási nyelvvel megegyezőek voltak, vagy a másik nyelven történt a bemutatás. Az eredmények azt mutatták, hogy a felidézés javult a bemutatás számának növekedésével. És ami még fontosabb, az illető szó egyszeri bemutatásához viszonyítva mind az ugyanazon a nyelven történő ismétlés, mind a különböző nyelveken való ismétlés ugyanolyan mértékben javította a szabad felidézést, így alátámasztva a nyelvtől való függetlenség elméletét.

GLANZER és DUARTE (1971) egy hasonló eredményről számolt be, egy kis módosítással. Amikor a bemutatások között időeltolódás volt, mint ahogy az előzőleg bemutatott kísérletben is, mind az ugyanazon a nyelven történő, mind a másik nyelven történő ismétlések egyformán hatásosak voltak (lásd még PAIVIO, CLARK, LAMBERT, 1988). Ezzel ellentétben, amikor az ismétlések szorosan követték egymást, a különböző nyelveken való ismétlések jobb teljesítményt eredményeztek, mint az ugyanazon a nyelven történő ismétlések. Ez a jelenség az elsajátítás változékonyságának tulajdonítható (MADIGAN, 1969) vagy annak, hogy nagyobb mértékben dolgozunk fel egy tételt a második megjelenésekor, amikor is a forma megváltozik (JACOBY, 1978).

A függőségi elméletet fenntartó más bizonyítékok a kategorizálási anyagokat használó szabad felidézési feladatokból származnak. Számos kutató bebizonyította, hogy amikor különböző fogalmi kategóriákból való szavakat kevert nyelvű listákon mutatnak be, a felidézés pontosan olyan jó, mint amikor a bemutatás egyetlen 
nyelven történik. Még akkor is, amikor ezeket a kevert nyelvü listákat véletlenszerủ sorrendben mutatják be; a személyek válaszaikat a szemantikus kategória alapján osztályozzák, és nem a bemutatási nyelv alapján. Tehát a szemantikus kategorizáció megelőzheti a nyelv szerinti kategorizációt a szabad felidézési feladat esetében (DALrymPLE-AlFord, AAMIRY, 1969; LAMBERT, IGNATOW, KRAUTHAMER, 1968).

Habár a fenti kísérletek a közös fogalmi képviselet elméletet támasztják alá, más kényszerítő erejü eredmények a nyelvtől való függés elméletét támogatják, nyelvspecifikus transzferhatásokat mutatva. Az ismétléses előfeszítési paradigmát, valamint a lexikális döntési feladatot használva számos kutató talált erre bizonyítékokat. Például, a lexikális döntési feladatban egy szónak ugyanazon a nyelven történő ismétlése csökkenti a reakcióidőt, viszont ilyenfajta haszon nem figyelhető meg, amikor az ingereket különböző nyelveken ismétlik meg (FISCHLER, BOAZ, Weidner, Randsdell, 1986; Kirsner, Brown, Abrol, Chadha, Sharma, 1980; Kirsner, SMith, LoCKhardt, King, Jain, 1984; SCARborough, Gerard, CORTESE, 1980); ez csak akkor történik meg, ha szándékosan olyan utasításokat adnak az személyeknek, hogy fordítsák le a szavakat első megjelenésük alkalmával (KirSNER, SMITH, LOCKHARDT, King, JAIN, 1984), vagy a szavak a két nyelvben alaktanilag hasonlóak (CRISTOFFANINI, KIRSNER, MILECH, 1986).

Egy másik kivétel a nyelvspecifikusság alól a lexikális döntés esetében az, amikor nem ismétlési, hanem szemantikus előfeszítést használnak. Amikor egy szemantikusan kapcsolódó előfeszítő szót mutatnak be a célszóval egyidőben vagy elötte, mind az ugyanazon nyelvü, mind a különböző nyelvü előfeszítő szavak szemantikus könnyítő (facilitáló) szerepet töltenek be (KIRSNER, SMITH, LOCKHARDT, KING, JAIN, 1984; SCHWANENFLugel, REY, 1986), de a szemantikus elóhangolási kísérletekben az előfeszítő szó és a célszó szünet nélkül van bemutatva, míg az ismétlési kísérletekben egy számottevő szünet van a két bemutatás között.

Egy ilyen nyelvspecifikus eredménymintázatot a töredékkiegészítési feladat esetében is találtak. WATKIns és PEYNiRCiOGLU (1983, 2. kísérlet) arra kérték török-angol kétnyelvủ személyeiket, hogy török vagy angol szólistákat tanulmányozzanak. Ezek után egy olyan feladatot adtak nekik, amelyben a töredékek egy olyan fogalmat jelenítettek meg, amely a) a tanulmányozás alatt használt nyelven volt, $b$ ) más nyelven volt vagy $c$ ) nem volt benne az eredeti listában. A kutatók az előzőleg nem tanulmányozott szavakhoz viszonyítva csak akkor tapasztaltak nyereséget ennél a feladatnál, amikor ugyanaz volt a teszt nyelve, mint a tanulmányozás nyelve; egy angol (vagy török) szó nem eredményezett jó teljesítményt amikor egy török (vagy angol) szórészlettel ellenőrizték le. A következtetés az, hogy - akár a lexikális döntés feladatban - a transzfer a töredékkiegészítési feladatban is nyelvspecifikus.

\section{A MENTÁLIS LEXIKON ÚJABB ELMÉLETEI}

John MorTon (1980) a szófeldolgozás számos jelenségének magyarázatára kidolgozott modellje (1. ábra) az egyike azoknak az általános modelleknek, amelyeket a 
kétnyelvű modellek bővítenek. Ez egy modulrendszer, amely arra a feltételezésre épül, hogy az egyedi folyamatok lényegében függetlenek egymástól. A logogén rendszer két részből áll: az input logogén rendszer szolgál a verbális ingerek kategorizálására és egyben a szövegben leírt facilitációs hatások helye; az output logogén rendszer tárolja a fonológiai kódokat. A kognitív rendszer minden szintaktikai és szemantikai feldolgozást magába foglal. A válasz puffer felelős az összes fonológiai kód beszéd outputba való konvertálásáért. A graféma-fonéma és az auditív-fonémikus utak bevezetését az értelmetlen szavak olvasási és elismétlési módja teszi szükségessé.

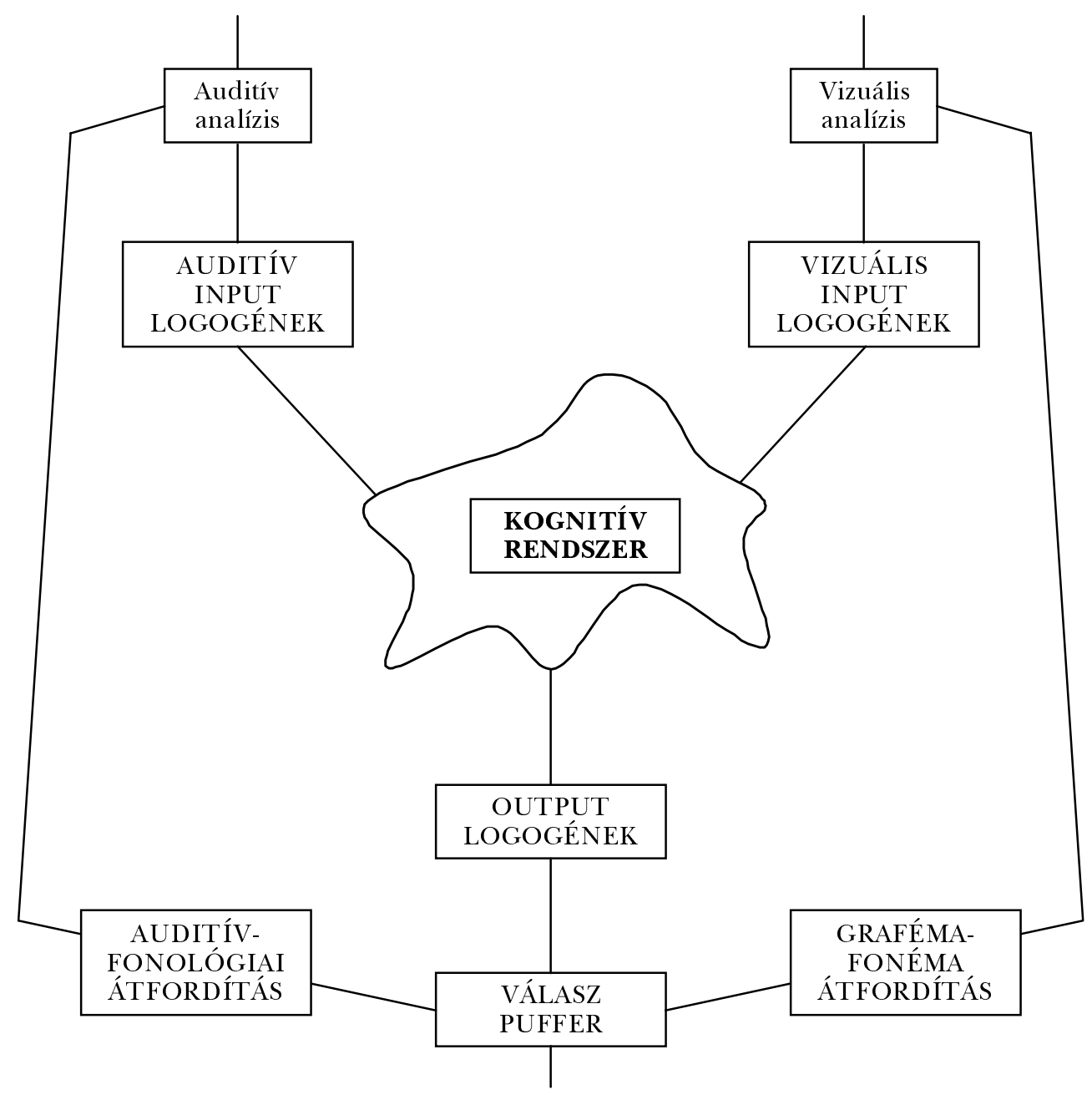

1. ábra. Morton logogén modellje 


\section{SZÓASSZOCIÁCIÓ, ILLETVE FOGALMI KÖZVETÍTÉS: A FEJLŐDÉSI HIPOTÉZIS}

Az egynyelvű modellek alapján dolgozták ki az ún. kétnyelvű modelleket.

Egyes kutatók (DurdunOglu, Roediger 1987; PotTer, So, vON ECKHARDT, FELDMAN 1984; SNODGRASS 1984) azt sugallják, hogy a szavak a két nyelvből lexikális szinten egymástól függetlenül vannak tárolva, ellenben fogalmi szinten mindkét nyelv ugyanazokkal a képzetekkel kerül kapcsolatba. Tehát a szavak és fogalmak olyan hierarchikus elrendeződéséről beszélhetünk, ahol lexikális szinten elkülönülés tapasztalható, viszont a fogalmi rendszer megosztott a nyelvek között.

Ez a hierarchikus modell magában nem pontosítja a kétnyelvúek két nyelve közötti kapcsolatok formáját. Lehet, hogy a két nyelv kölcsönösen egymáshoz kapcsolt lexikális szinten, vagy a közös fogalmi reprezentáció révén. Az első hipotézis, a szóasszociáció-hipotézis azt veti fel, hogy a szavak az idegen nyelven inkább a megfelelő anyanyelvi szavakhoz kapcsolódnak, mint az őket alátámasztó amodális fogalmakhoz. Ezek a kapcsolatok válnak aktívvá akkor, amikor egy ember az idegen nyelvét használja. A második hipotézis, a fogalmi közvetítés hipotézise azt mondja ki, hogy egy kétnyelvủ anyanyelve és idegen nyelve egymástól függetlenül működik, úgy, hogy a szavak a két nyelvből nem közvetlen kapcsolatban állnak, hanem egy amodális fogalmi rendszer köti össze őket. Mindkét modell megkülönböztet a kétnyelvű memóriában két szintet, egy lexikálisat és egy fogalmit, és ezért nevezzük őket „hierarchikus modelleknek” (ANDERSON, BOWER, 1973; POTTER, 1979; SNODGRASS, 1980; 1984). Mindkét hipotézis feltételezi két különálló lexikon létét, egyet-egyet a két nyelv számára, a különbség a különböző memóriakészletek közötti kapcsolat. A szóasszociáció modell közvetlen kapcsolatot feltételez a két lexikon megfelelő képzetei között, viszont nincsenek közvetlen kapcsolatok a második, gyengébb nyelv szavainak lexikális reprezentációi és a fogalmi memória aszszociált fogalmi képzetei között. Következésképpen, a második nyelvű szavak fogalmaikat csak közvetetten érhetik el, vagyis az első nyelvű fordítás lexikális képzetei révén. Ezzel ellentétben a fogalmi közvetítés modellje tagadja a fordítási pár lexikális reprezentációi közötti direkt kapcsolatot, viszont közvetlen kapcsolatokat feltételez a második nyelvủ lexikális készlet képzetei és a fogalmi memória asszociált fogalmai között. Így a második nyelvű szó közvetlenül megközelítheti a fogalmi memóriát (lásd 2. ábra). Mindkét modell azt feltételezi, hogy a fogalmi emlékezetben a képzetek megosztottak a fordítási megfelelők szavai között, vagyis a fogalmi képzet nyelvtől független. Persze az első nyelv lexikona több elemet fog tartalmazni, mint a második nyelvé. Ezt a 2. ábrán a lexikonokat megjelenítő körök nagyságbeli különbsége mutatja.

A szóasszociáció és a fogalmi közvetítés modellek WEINREICH (1953) kétnyelvű reprezentációs struktúráiból erednek. Az „alárendelt” (szóasszociáció) és az „öszszetett" (fogalmi közvetítés) struktúrák esetében Weinreich a két nyelv által megosztott, nyelvtől független fogalmi reprezentációt feltételezett; egy harmadik, a „mellérendelt” struktúra létezését is feltételezte, amelyben az első, illetve második nyelvű szavak különböző, nyelvspecifikus fogalmi reprezentációkat érnek el. Az, hogy egy fordítási pár egyetlen nyelvtől független fogalmi reprezentációban meg- 
Szóasszociáció

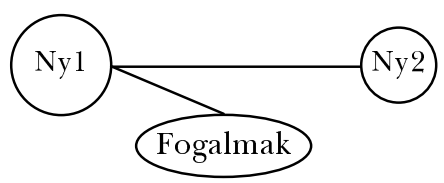

Fogalmi közvetítés

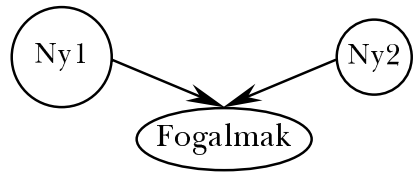

2. ábra. A kétnyelvűek memóriájának modelljei

jelenített vagy két nyelvspecifikus fogalmi reprezentációban, egy sor tényező függvénye, ezek közé sorolható a kétnyelvü egyén nyelvtörténete (ERVIN, OSGOOD, 1954) és a szó típusa (DEGROOT, 1993).

Újabb keletű vizsgálatok (CHEN, LEUnG, 1989; Kroll, Curley, 1988; DE Groot, Dannenburg, VAN Hell, 1994) azt mutatták ki, hogy a második nyelv elsajátításának kezdeti szakaszában az egyének a két nyelv szavai közötti társításokra (asszociációkra) támaszkodnak, tehát a nyelvek lexikális szinten vannak öszszekapcsolva. Ahogy nagyobb jártasságra tesznek szert az idegen nyelv terén, a kétnyelvűek képessé válnak arra, hogy közvetlenül a fogalmakkal dolgozzanak, az első nyelv közreműködése nélkül. Ez a kétnyelvűek fejlődési hipotézise. Ezt támasztja alá Thuma Orsolya és PléH Csaba kísérlete is (1995), amely azt mutatta ki, hogy a gyakorlott kétnyelvűek esetében a kétértelmű szavak mindkét jelentésének asszociátumai mind a két nyelven aktiválódnak egy rövid ideig. JAROVINSKIJ (1997) vizsgálata azt mutatta, hogy fiatal, óvodás kétnyelvűek mentális szótára egymással szoros kapcsolatban levő és független rendszerekből tevődik össze. A kétnyelvű kompetencia növekedésével egyes szavak és jelentései, amelyek kezdetben összetett módon szervezettek a kényelvűek agyában, később a mellérendelt lexikai reprezentáció vonásait mutathatják.

KROLL és STEWART (1994) kidolgozták a hierarchikus modellnek egy új változatát, amely a kétnyelvűek emlékezeti képzetrendszerét mutatja be. Ez a modell számot ad a nyelvtudás tökéletesedésével bekövetkező, a szavakról a fogalmakra való áttérésről (3. ábra).

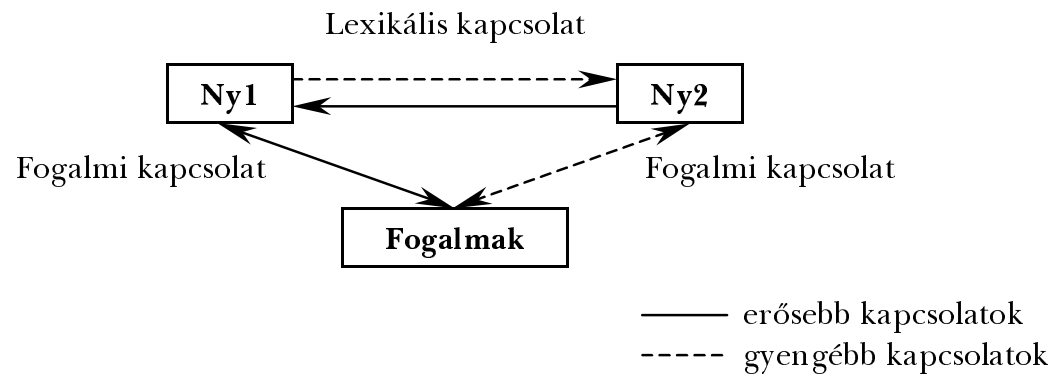

3. ábra. Az átdolgozott hierarchikus modell (KROLL, STEWART, 1994) 


\section{HIPOTÉZISEK}

Tekintetbe véve, hogy a különböző feladatok eltérő előhívási követelményei eltérő eredménymintázatokra és egymással ellentétes következményekhez vezetnek, a kétnyelvủek információtárolásáról szóló vita végtelennek tűnhet. Ennélfogva valószínű, hogy gyümölcsözőbb elemzést tesz lehetővé egy kódolási specifikusság központú szemlélet, amelyben az emlékezeti próbákon való teljesítmény olyan mértékben javul, amilyen mértékben a teszt által megkövetelt eljárások megismétlik az elsajátítási eljárásokat (DURDUNOGLu, ROEDIGER, 1987).

A szabad felidézéshez hasonló feladatok esetében általában a nyelvtől való függetlenség figyelhető meg, míg a töredékkiegészítéses és lexikális döntéshez hasonló feladatok esetében a nyelvtől való függőség. Mivelhogy ez a következtetés különböző kísérletek összehasonlításából fakad, szükségesnek láttam ezt bebizonyítani egyetlen kísérletben, amely egyforma elsajátítási feltételeket és különböző emlékezeti próbákat használ. Jelen dolgozat egyik célja azonosítani azokat a feltételeket, amelyek a nyelvtől való függőség és nyelvtől való függetlenség eredménymintázatait vonják maguk után háromnyelvủek esetében.

Kísérletemben a magyar-román-angol háromnyelvű személyek különböző stratégiák segítségével vésték be a szavakat, majd el kellett végezzenek egyet a három emlékezeti feladat közül. A próbák a következők voltak: szabad felidézés, igen/nem felismerés és előfeszítés töredékkiegészítés révén. JACOBY (1983), RoEdiger és BLAXTON (1987b), valamint DuRdunOgLu és RoEdiger (1987) elemzése szerint a szabad felidézés egy fogalmilag irányított emlékezeti feladatnak tekinthető, mivel ilyenkor a személyek nem kapnak olyan nyilvánvaló jelzéseket a szóból, amelyek irányíthatnák a teljesítésüket, és így a jelentésre kell támaszkodjanak. Számos tényezó, ami úgy ismert, mint olyan, ami segíti a szabad felidézést képformálás, szemantikus feldolgozás a másfajta (fonémikus, grafémikus) feldolgozási formákkal ellentétben, információgenerálás az olvasással ellentétben és a mélyreható feldolgozás más változatai - segíti a fogalmilag irányított feldolgozást is. A felszíni formában, például modalitásban vagy nyelvben való változások viszont nem befolyásolják a szabad felidézést.

Másfelől a Tulving, SCHACHTER és STARk (1982) által használt töredékkiegészítési feladat, amelyben a személyek olyan szótöredékeket kell kiegészítsenek, amelyeket nemrég láttak már (például n_gy_am_ nagymama helyett), úgy tekinthető, mint az adatok által irányított feldolgozást igénylő feladat (ugyanúgy, ahogy az előfeszítés a perceptuális azonosításban, a lexikális döntés és más feladatok). Az alapötlet az, hogy ezeknél a feladatoknál az előfeszítés azt feltételezi, hogy a hiányos adatokra adott válaszok függjenek a tanulmányozás és próbán való bemutatás felszíni jellegzetességeinek összehangolásától. Például, vizuális töredékkiegészítési próbákat használva ROEDIGER és BLAXTON (1987a) nagyobb mértékű előfeszítést mutatott ki a vizuális szóbemutatás esetén, mint a hallási esetén; WELDON és ROEDIGER kísérletében (1987) nagyobb haszon származott a verbális címke referensét reprezentáló szavak tanulmányozásából, mint az ugyanezt reprezentáló képek tanulmányozásából. Másrészt, a töredékkiegészítési feladat számára kevés előny származik a fogalmi feldolgozás manipulációiból. Például, ugyanúgy, 
mint a perceptuális azonosítás, a töredékkiegészítés is egy fordított generációs hatást mutat, vagyis jobban egészítjük ki azokat a szavakat, amelyeket a tanulmányozás ideje alatt olvassuk, mint azokat, amelyeket generáljuk (BLAXTON, 1985; JACOBY, 1983). ROEDIGER és BLAXTON (1987b) más bizonyítékokat is felhoz arra, hogy az előfeszítés a töredékkiegészítés terén adatvezérelt.

Az általam használt harmadik feladatról, az igen/nem felismerésről úgy tartják, hogy akármelyik vagy mindkét folyamat véghezviheti: az adatvezérelt és a fogalmilag vezérelt is (DuRDunOGLu, RoEDiger, 1987; JACOBY, DALlas, 1981; MANDLER, 1980). A felismerés végbemehet egy gyors ismerősségi folyamat révén, ami megfelel az adatvezérlet feldolgozásnak, vagy egy lassúbb, nehézkesebb fogalmi keresőfolyamat révén (JOHNSTON, DARK, JACOBY, 1985; MANDLER, 1980). Célom ennek a feladatnak a beiktatásával az volt, hogy megkíséreljem kimutatni a háromnyelvűek memóriájában az adatvezérelt és fogalmilag vezérelt folyamatok kombinációját.

Kísérletemben magyar-román-angol háromnyelvűeket használtam. Ezek a személyek nagyon korán elkezdték tanulni a román nyelvet, az ún. szenzitív periódusban (0-6 éves kor, JOHNSON, NEWPORT, 1989), tehát a román nyelvet folyékonyan, gyakorlottan beszélők közé sorolhatjuk őket. Ha a fejlődési hipotézis megalapozott, akkor ezek a személyek fogalmilag közvetítik a román nyelvet, ugyanúgy, mint az anyanyelvüket, a magyart.

Az egyik kérdésem, amire választ szerettem volna kapni a kísérletből, az volt, hogy létezik-e lexikális kapcsolat a személyek második és harmadik nyelve között vagy mindkét nyelvet fogalmilag közvetítik gyakorlottsági fokuktól függetlenül. Két csoportot alkalmaztam, az egyik csoport olyan kísérleti személyekből állt, akik épp elkezdték tanulni a harmadik nyelvüket (ezek voltak a kevésbé folyékonyan beszélő háromnyelvűek), a másik csoport olyan folyékonyabban beszélő háromnyelvűekből állt, akik már elértek egy bizonyos szintet az angol nyelv tanulásában. Egyik hipotézisem az volt, hogy az első csoport különböző eredménymintázatokat fog produkálni a különféle feladatok során, viszont a második csoport egy homogénebb mintázatot fog mutatni, a feladatoktól függetlenül.

Öt különböző elsajátítási feltételt alkalmaztam a kísérlet tanulmányozási szakaszában. A személyek kétszer látták a szavakat, $a$ ) román nyelven, $b$ ) angol nyelven vagy $c$ ) román nyelven egyszer és angol nyelven egyszer. Más szavakat a személyek d) román nyelven láttak, majd le kellett írják a szó angol megfelelöjét vagy e) kétszer látták a szót románul, mint az a) esetében, s ezen kívül generálniuk kellett egy képet is a szóról. Azt feltételeztem, hogy ezek az elsajátítási feltételek egymástól eltérően vivődnek át a három tesztformára, mivelhogy különböző mértékben igényelnek adatvezérelt, illetve fogalmilag vezérelt feldolgozást. Például, a $d$ ) és az $e$ ) vizsgálódási feltételeknek serkenteniük kell a fogalmilag vezérelt feldolgozást és elő kell segíteniük a szabad felidézést, viszont kis hatással vagy egyáltalán nem kéne hatással lenniük a töredékkiegészítési feladatra, ami egy adatvezérelt feladat. Másrészt a vizsgálódás nyelvének változtatása feltevésem szerint kismértékben kell befolyásolja a szabad felidézési feladatot, és nagymértékben a töredékkiegészítési próbát. Tekintetbe véve, hogy a töredékkiegészítési feladat angolul volt megadva, nagyobb előfeszítés várható a szavak angol nyelven való tanulmányozásától, mint a 
román nyelven való tanulmányozástól. Hipotézisemnek megfelelően a fordítás és elképzelés által megkövetelt fogalmi feldolgozás kismértékben kell befolyásolja az előfeszítést a töredékkiegészítési feladat során. A felismerési próbát mind az adatvezérelt, mind a fogalomvezérelt feldolgozásnak befolyásolnia kell, így egy, a szabad felidézéstől és a töredékkiegészítéstôl is eltérő teljesítménymintázatot mutatva. Mindezt a kevésbé folyékonyan beszélő csoport esetében várom el. A gyakorlottabb csoport egyénei mindkét nyelvet fogalmilag kell közvetítsék, így alátámasztva a függőségi elméletet, konkrétabban KROLL és STEwART modelljét (1994). Tehát egy másik célom az volt, hogy bizonyítékokat gyüjtsek a fejlődési hipotézis mellett háromnyelvűek esetében.

\section{MÓDSZER}

\section{A kisérleti személyek}

A kísérletben 72 magyar-román-angol háromnyelvű vett részt, akik 11 és 16 év közötti iskolások voltak egy kolozsvári magyar iskolából. Anyanyelvük a magyar, otthon is és az iskolában is ezen a nyelven beszélnek. Egyikük otthonában az angol is használatos a magyar mellett, míg egy másik személy esetében mindhárom nyelven beszélnek otthon is (töredékkiegészítési csoport, folyékonyabban beszélő személy). A felidézési csoportban egy kevésbé folyékonyan beszélő kísérleti személy románul is beszél otthon, és két gyakorlottabb háromnyelvủ román óvodába járt (egyikük még mindig használja otthon a román nyelvet). A személyek közül 30 fiú, a többi lány. A 1. táblázat tartalmazza az adatokat arra vonatkozólag, hogy a személyek mikor kezdték el tanulni a román és az angol nyelvet.

1. táblázat. A román és angol nyelv tanulásának kezdete - összehasonlítás

\begin{tabular}{|c|c|c|c|}
\hline & Román nyelv* & Angol nyelv** & \\
\hline \multicolumn{4}{|c|}{ SZABAD FELIDÉZÉS } \\
\hline KFBa & $\mathrm{m}=2,91 \quad$ (szórás $=0,66)$ & $\mathrm{m}=14,08 \quad($ szórás $=0,66)$ & \multirow{2}{*}{$\begin{array}{l}\text { FBa }>\text { KFBa, } \\
\mathrm{t}=3,72 ; \mathrm{p}=0,001\end{array}$} \\
\hline FBa & $\mathrm{m}=3,5 \quad$ (szórás $=1,62)$ & $\mathrm{m}=9,16 \quad($ szórás $=1,8)$ & \\
\hline \multicolumn{4}{|c|}{ SZÓKIEGÉSZÍTÉS } \\
\hline KFBa & $\mathrm{m}=4,16$ (szórás $=1,19)$ & $\mathrm{m}=13,16$ (szórás $=2,2)$ & \multirow{2}{*}{$\begin{array}{l}\text { FBa }>\text { KFBa, } \\
\mathrm{t}=3,09 ; \mathrm{p}=0,005\end{array}$} \\
\hline FBa & $\mathrm{m}=4,41 \quad$ (szórás $=1,37)$ & $\mathrm{m}=10,08 \quad($ szórás $=3,11)$ & \\
\hline \multicolumn{4}{|c|}{ FELISMERÉS } \\
\hline $\mathrm{KFBa}$ & $\mathrm{m}=3,25 \quad($ szórás $=1,95)$ & $\mathrm{m}=13,33 \quad$ (szórás $=2,14$ ) & \multirow{2}{*}{$\begin{array}{l}\mathrm{FBa}>\mathrm{KFBa} \\
\mathrm{t}=2,36 ; \mathrm{p}=0,02\end{array}$} \\
\hline $\mathrm{FBa}$ & $\mathrm{m}=3,08 \quad($ szórás $=1,05)$ & $\mathrm{m}=9,58 \quad($ szórás $=1,72)$ & \\
\hline
\end{tabular}

* román nyelv tanulásának kezdeti éve

** angol nyelv tanulásának kezdeti éve
KFBa - kevésbé folyékonyan beszélők angolul

FBa - folyékonyan beszélók angolul 
A folyékonyan beszélő személyek és a kevésbé folyékonyan beszélók között szignifikáns különbséget találtam az angol nyelv tanulásának kezdeti évére vonatkozóan: a szabad felidézési feladat esetében $t=3,72, p=0,001$; a töredékkiegészítési feladat esetében $t=3,09, p=0,005$; a felismerési feladat esetében pedig $\mathrm{t}=2,36, \mathrm{p}=0,02$. Ilyen különbség nem állt fenn a román nyelvet illetően.

A kevésbé folyékonyan beszélő csoport a kísérlet megkezdése előtt 5 hónappal kezdte tanulni az angol nyelvet, és nem gyakorolták csak az iskolában.

Mindegyik kísérleti személy a magyart tekintette anyanyelvének és a románt a második nyelvének.

\section{Kísérleti anyagok}

A kísérletben 50 angol szót és ezek román fordításait használtam (lásd a 2. táblázatot). Minden szó nagy gyakoriságú, könnyen elképzelhető ingereket nevezett meg. Paivio, Yuille és Madigan (1968), SNODgrass és Vanderwart (1980), valamint DURDUNOGLU és RoEDIGER (1987) normáiból válogattam ezeket a szavakat. Előzőleg megbizonyosodtam arról, hogy a kísérleti személyek ismerik ezeket a szavakat angolul: megvizsgáltam angol nyelvkönyveiket és megkérdeztem angol tanáraikat is. A töredékkiegészítési feladat esetében az angol szavakból kitöröltem bizonyos betűket. A szótöredékeket három ember előzetesen már kitöltötte, így megbizonyosodtam arról, hogy csak egy megoldás létezik az egyes részletek kitöltésére. A szavak román fordításait is megvizsgálta két anyanyelvủ román a fordítás pontosságát ellenőrizendő. Ezek után az angol szavakat véletlenszerủen 6 tízes csoportba rendeztem. Mindegyik szócsoportot egyetlen elsajátítási feltételben használtam.

A kísérlet egy elsajátítási és egy tesztfázisból állt. Az első szakaszban a személyek egy szót láttak a képernyőn, majd megnéztek az előttük levő könyvecskében egy másik tételt. Öt elsajátítási feltétel volt: a) olvasd románul: ebben az esetben az személyek a képernyőről elolvasták a román szót, majd ugyanezt a szót elolvasták a könyvecskéből is; $b$ ) olvasd angolul: ebben az esetben ugyanazt kellett tenniük, mint az a) esetben azzal a különbséggel, hogy a szó két bemutatása angolul volt; c) olvasd románul és angolul: a képernyőn a szó románul volt, a könyvecskében pedig angolul; (a fenti esetek mindegyikében megkértem az személyeket, hogy magukban olvassák a szavakat) d) fordítsd le: ebben az esetben mindegyik szó román nyelven jelent meg a képernyőn, a könyvecskében pedig a szó angol megfelelöjének kezdőbetűje volt megadva; a személyek el kellett olvassák a román szót a képernyőről, majd be kellett írják a szó angol megfelelőjét a könyvecskébe; e) képzeld el: a szavak mind a képernyőn, mind a könyvecskében románul voltak megadva, mint az a) esetben, a kísérleti személyeknek viszont el is kellett képzelniük azt, amit a szó jelölt.

Egy hatodik szócsoportot nem látták a személyek, ez azért volt beiktatva a felismerési és töredékkiegészítési próbába, hogy felmérjem a hamis riasztás arányát (false alarm rate) és a töredékkiegészítések alaparányát (base rate of fragment completions). 


\begin{tabular}{|c|c|c|c|c|c|c|c|c|c|c|}
\hline 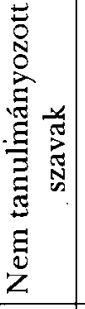 & 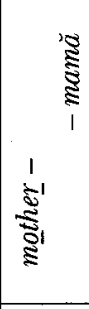 & 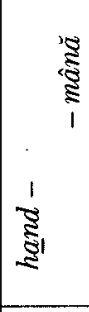 & 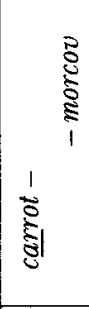 & 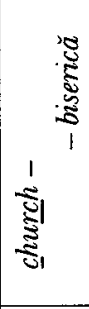 & $\begin{array}{l}\text { हूँ } \\
\frac{\Xi}{1} \\
1 \\
\text { हो। } \\
\text { हो }\end{array}$ & 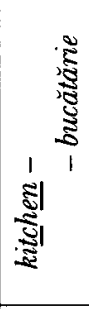 & $\begin{array}{l}1 \\
\text { s̀' } \\
\text { sેl }\end{array}$ & $\frac{1}{\dddot{Z}}$ & $\begin{array}{l}1 \\
\text { है। }\end{array}$ & $\frac{1}{\widetilde{a}_{1}^{\prime}}$ \\
\hline $\begin{array}{l}\bar{\Xi} \\
\bar{u} \\
\stackrel{u}{u} \\
\ddot{u}\end{array}$ & 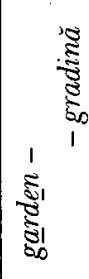 & 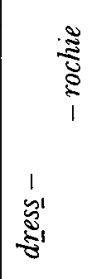 & $\frac{3}{1}$ & 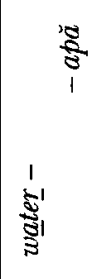 & 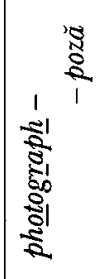 & 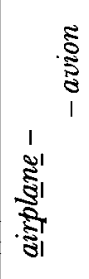 & 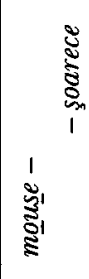 & 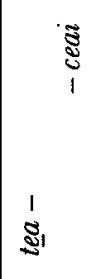 & '. & $\frac{1}{\widetilde{\sigma}^{\prime}}$ \\
\hline 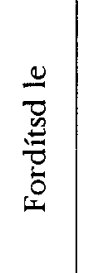 & 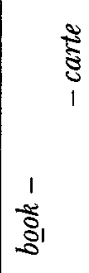 & 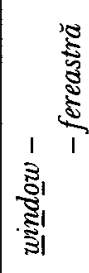 & 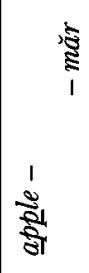 & 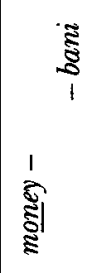 & 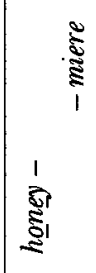 & 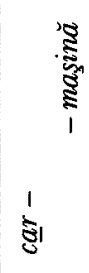 & 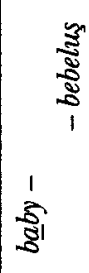 & 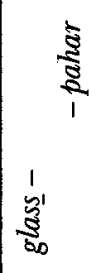 & 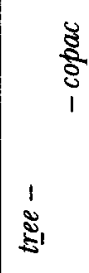 & 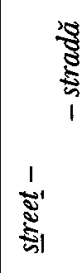 \\
\hline 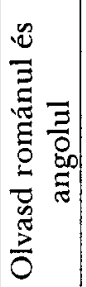 & 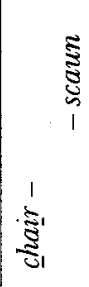 & 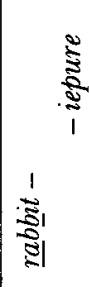 & 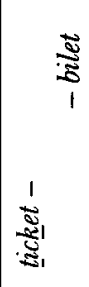 & 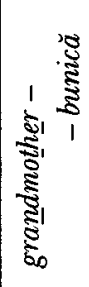 & 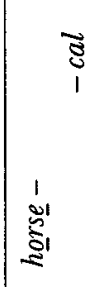 & 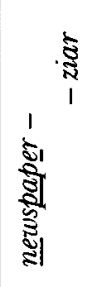 & 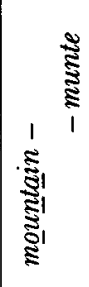 & إل & 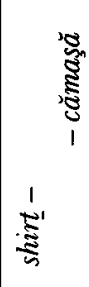 & 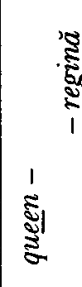 \\
\hline 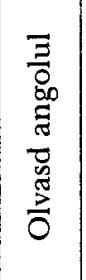 & 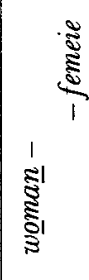 & 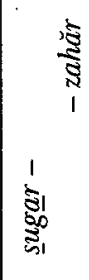 & $\frac{\mathrm{s}}{\mathrm{g}}$ & 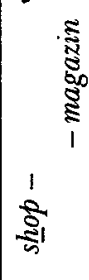 & 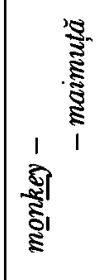 & 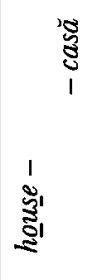 & 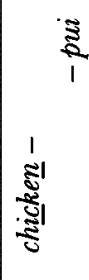 & 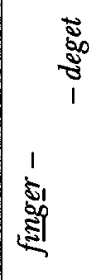 & 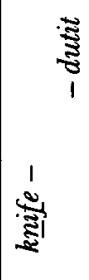 & 立 \\
\hline 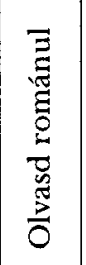 & 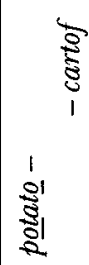 & $\mid$ & 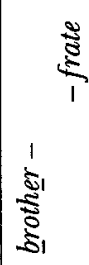 & 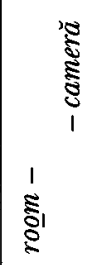 & 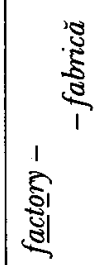 & 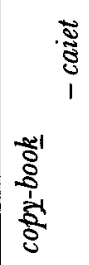 & 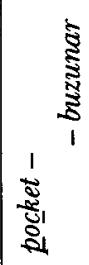 & $\mid$\begin{tabular}{l}
1 \\
\multirow{\Xi}{\Xi}{} \\
$\Xi^{\prime}$
\end{tabular} & 孚 & 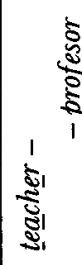 \\
\hline
\end{tabular}


Az elsajátítási feltételeket minden személy esetében változtattam. Mindegyik elsajátítási feltétel esetében a tételek tömbökben voltak bemutatva. Mindegyik kísérleti személy a feladatot megelőzően összesen 50 szót tanulmányozott az öt elsajátítási feltétel során. A elsajátítás után a személyek különböző csoportjai egy-egy feladatot kaptak megoldásra; mindegyik csoport 12 személyből állt. A felismerési és töredékkiegészítési próbáknál a személyek minden vizsgált szót (vagy ezek részleteit) láttak, valamint 10 nem vizsgáltat is. Így a kísérlet elrendezése egy 2 (kezdők és folyékonyan beszélő személyek) * 5 (tanulási feltételek) * 3 (a feladat típusa) kevert faktoriális volt, két kiegészítő ablakkal a felismerési és töredékkiegészítési feladat esetében a nem vizsgált tételek számára.

A töredékkiegészítési és felismerési próbák angol nyelvűek voltak. A könyvecskében az 50 tétel ugyanolyan sorrendben volt, mint a bemutatás során, csakhogy a 10 nem vizsgált tételt véletlenszerúen beszúrtam közéjük.

\section{Eljárás}

A kísérlet kezdetén elmondtam a személyeknek, hogy román és angol szavakat kell tanulmányozzanak a képernyőről és a nekik kiosztott könyvecskékből annak érdekében, hogy majd megoldjanak egy emlékezeti próbát, amelynek a jellegét nem pontosítottam.

A kísérlet tanulmányozási szakaszában a szavak 10 mp-es egymásutánban voltak mutatva. Az utasításokat a különböző szócsoportok bemutatása előtt megadtam. Az olvasd angolul, olvasd románul és az olvasd románul és angolul feltételeknél arra kértem a kísérleti személyeket, hogy először olvassák el a képernyőn megjelenő szót, majd olvassák el a szót a könyvecskéből. A fordítsd le feltétel esetén arra kértem őket, hogy olvassák el a román szót, majd írják be a könyvecskébe a szó megfelelő angol fordítását. Felhívtam a figyelmüket arra, hogy a könyvecskében megjelenő betű a román szó angol megfelelőjének az első betủje. A képzeld el feltétel esetén arra kértem az személyeket, hogy olvassák el a román szót a képernyőről és a könyvecskéjükben, majd képzeljék el a szót. Az öt szócsoport tanulmányozása után egy rövid utasítást követően a személyek elvégezték a három feladat egyikét.

A szabad felidézés esetében a személyeket arra kértem, hogy írják fel egy papírra azokat a szavakat, amelyeket előzőleg tanulmányoztak. Az egyes szavakat akár románul, akár angolul is leírhatták. A 8 perces felidézési szakasz alatt mindig kellett húzzanak egy-egy vonalat az 1 perc alatt felidézett szavak után. Esetenként, ha egy személy arról panaszkodott, hogy nem képes már több szót felidézni, bátorítottam őt. Amikor a felidézési idő lejárt, arra kértem őket, hogy fordítsák le angolra mindazokat a szavakat, amelyeket románul írtak le.

A töredékkiegészítéses feladat esetén a személyek azt az utasítást kapták, hogy az előttük levő 60 hiányos szót úgy egészítsék ki, hogy egy angol nyelven értelmes szó legyen az eredmény. Azt nem említettem, hogy a tételek legtöbbje az előzőleg már tanulmányozott szavakból került ki. A szótöredékek le voltak gépelve egy papírra és a kísérleti személyeknek 20 percük volt arra, hogy kiegészítsék őket. 
Így egy részletre 20 másodperc jutott. Egy személy sem panaszkodott, hogy ennyi idő alatt nem tudta befejezni a feladatot.

A felismerési feladat esetében a személyek be kellett karikázzák a megadott 60 szó közül azokat, amelyek be voltak mutatva a tanulmányozási időszak alatt. Az utasítások kihangsúlyozták, hogy annak ellenére, hogy az előttük levő lista csak angol nyelvű szavakat tartalmaz, ők minden szót ki kell jelöljenek, függetlenül attól, hogy előzőleg milyen nyelven látták azt. Adtam egy példát is az előzőleg nem tanulmányozott „farkas” szó segítségével: akkor is be kellett karikázzák a felismerési listán, ha a szó angol „woolf” megfelelöjét látták a tanulmányozási idő alatt és akkor is, ha a román „lup” megfelelőt, sőt még akkor is, ha mindkét változatot. A felismerési feladat esetében mindegyik személy maga gazdálkodott az idejével. A feladatok befejeztével elmagyaráztam a személyeknek a kísérlet lényegét.

\section{EREDMÉNYEK}

A 3. táblázat mutatja a helyes válaszok százalékát a kevésbé folyékonyan beszélő személyek esetében, a 4. táblázat pedig a folyékonyabban beszélő személyek esetében.

3. táblázat. A helyes itemek százaléka a kevésbé folyékonyan beszélők csoportjában

\begin{tabular}{|l|c|c|c|}
\cline { 2 - 4 } \multicolumn{1}{c|}{} & \multicolumn{3}{c|}{ A feladat típusa } \\
\hline Bevésési feltételek & $\begin{array}{c}\text { Szabad } \\
\text { felidézés }\end{array}$ & $\begin{array}{c}\text { Igen/nem } \\
\text { felismerés }\end{array}$ & $\begin{array}{c}\text { Szó- } \\
\text { kiegészítés }\end{array}$ \\
\hline Olvasd románul (maimuță, maimuță) & $24 \%$ & $23 \%$ & $46 \%$ \\
\hline Olvasd angolul (monkey, monkey) & $15 \%$ & $72 \%$ & $64 \%$ \\
\hline Olvasd románul és angolul (maimuță, monkey) & $43 \%$ & $70 \%$ & $65 \%$ \\
\hline Fordítsd le (maimuță, m & $50 \%$ & $64 \%$ & $71 \%$ \\
\hline Képzeld el (maimuțã, (maimuță) & $65 \%$ & $46 \%$ & $66 \%$ \\
\hline Nem tanulmányozott szavak & - & $8 \%$ & $55 \%$ \\
\hline
\end{tabular}

4. táblázat. A helyes itemek százaléka a folyékonyan beszélők csoportjában

\begin{tabular}{|l|c|c|c|}
\cline { 2 - 4 } \multicolumn{1}{c|}{} & \multicolumn{3}{c|}{ A feladat típusa } \\
\hline Bevésési feltételek & $\begin{array}{c}\text { Szabad } \\
\text { felidézés }\end{array}$ & $\begin{array}{c}\text { Igen/nem } \\
\text { felismerés }\end{array}$ & $\begin{array}{c}\text { Szó- } \\
\text { kiegészítés }\end{array}$ \\
\hline Olvasd románul (maimuță, maimuță) & $35 \%$ & $69 \%$ & $68 \%$ \\
\hline Olvasd angolul (monkey, monkey) & $24 \%$ & $85 \%$ & $71 \%$ \\
\hline Olvasd románul és angolul (maimuță, monkey) & $40 \%$ & $88 \%$ & $70 \%$ \\
\hline Fordítsd le (maimuță, m & $40 \%$ & $87 \%$ & $75 \%$ \\
\hline Képzeld el (maimuță, (maimuță) & $62 \%$ & $87 \%$ & $74 \%$ \\
\hline Nem tanulmányozott szavak & - & $5 \%$ & $60 \%$ \\
\hline
\end{tabular}


Egy átfogó varianciaanalízist végeztem a három feladaton elért helyes megoldás számán; ez magába foglalta az öt különböző tanulmányozási feltételt a két személycsoportra nézve. A következő főhatások voltak szignifikánsak: az angolban való jártasság foka, $\mathrm{F}(1,70)=206, \mathrm{p}<0,001$; a feladat jellege, $\mathrm{F}(2,560)=70,89$, $\mathrm{p}<0,001$ és a különböző tanulmányozási feltételek, $\mathrm{F}(4,560)=49,15, \mathrm{p}<0,001$. Még érdekesebb viszont az, hogy az összes páros interakciót is szignifikánsnak találtam: a gyakorlottsági szint és a tanulmányozási feltételek interakciója esetén $\mathrm{F}(4,560)=88,57$, a gyakorlottsági szint és a feladat jellege esetén $\mathrm{F}(2,560)=$ $=1080,34$, a tanulmányozási feltételek és a feladat jellege interakciója esetén pe$\operatorname{dig} \mathrm{F}(8,560)=23,61(\mathrm{p}<0,001$ mindegyik interakciónál). Ezek a páros interakciók azt jelentik, hogy mind a tanulmányozási feltételek, mind a gyakorlottsági szint különböző hatással volt a három feladatra, ennélfogva a feladatokat és a kísérleti személyek csoportjait külön fogom elemezni.

A feladatok terén elért helyes megoldásokon végzett varianciaanalízis a különböző tanulmányozási feltételek esetében - külön a kevésbé folyékonyan beszélő személyekre és külön a folyékonyabban beszélő személyekre - kihangsúlyozta a fent leírt eredményeket. Mindkét csoport esetében a feladat típusa és a tanulmányozási feltételek fóhatásként szignifikánsak voltak: $\mathrm{F}(2,33)=6,71, \mathrm{p}<0,01$, $\mathrm{F}(4,132)=13,72, \mathrm{p}<0,001$ (kevésbé folyékonyan beszélők), $\mathrm{F}(2,33)=25,79$, $\mathrm{p}<0,001 ; \mathrm{F}(4,132)=53,76, \mathrm{p}<0,001$ (folyékonyabban beszélók). A feladat és a tanulmányozási feltételek közötti interakció szintén szignifikáns volt mindkét csoport esetében: $\mathrm{F}(8,132)=6,92$ a kevésbé gyakorlott személyeknél, $\mathrm{F}(8,132)=$ $=274,36$ a gyakorlottabb személyeknél (mindkét esetben $\mathrm{p}<0,001$ ).

\section{Szabad felidézés}

1. Kevésbé folyékonyan beszélő csoport

A 3. táblázat második oszlopa mutatja a helyesen felidézett szavak arányát az egyes tanulmányozási feltételek esetén; az ezen végzett variancianalízis a tanulmányozási feltételek főhatását mutatja: $\mathrm{F}(4,44)=8,32, \mathrm{p}<0,001$.

A tanulmányozási feltételek t-próbával végzett összehasonlítása azt jelezte, hogy felidézés szintje nem volt megbízhatóan különböző az olvasd románul és olvasd angolul feltételek között $(0,24$ és 0,15$)$. Az első feltétel csekély előnye annak tulajdonítható, hogy a személyek a román nyelvet nagyon hamar elkezdték tanulni.

A fennmaradó három feltétel nem különbözött egymástól (olvasd románul és angolul: 0,43, fordítsd le: 0,5, képzeld el: 0,65), viszont ezek szignifikánsan jobb felidézést eredményeztek az olvasd angolul és olvasd románul feltételekkel szemben. Tehát, amikor a személyek egy angol fordítást vagy egy képet generáltak egy román szóhoz, a felidézés javult. Ez viszont aláhúzza a generálás és a képzelet (PAIVIO, 1969) jótékony hatásait és azt mutatja, hogy a szabad felidézés javul a mélyreható feldolgozással. Nem találtam szigorú értelemben vett generálási hatást, mivel a teljesítmény a fordítsd le feltételben $(0,5)$ nem sokkal haladta meg az olvasd románul és angolul feltételben való teljesítményt $(0,43)$. 
Az olvasd angolul és románul feltételben a felidézés egy picit jobb volt $(0,43)$, mint az olvasd románul feltétel esetén $(0,24), \mathrm{t}=1,58, \mathrm{p}=0,1$, vagy az olvasd angolul feltétel esetén $(0,15), t=2,56, p=0,01$. Ez a tendencia aláhúzza GLANZER és DUARTE (1971) elképzelését, miszerint a tömeges bemutatásoknál - ami az én kísérletemet is jellemzi - a szó két különböző formában való bemutatása javítja a felidézést. Az egymástól nagyobb távolságban levő bemutatásokkal ez a hatás eltűnik. Így, az olvasd románul és angolul feltétel előnye az olvasd románul és olvasd angolul feltételekkel szemben nem problematikus a nyelvtől való függetlenség elmélete szempontjából, a tömeges bemutatások elsajátítási változékonyságának tulajdonítják (MADIGAN, 1969), vagy az ismétlés révén elért kiegészítő feldolgozásnak (JACOBY, 1978).

2. A folyékonyabban beszélő csoport

A 4. táblázat második oszlopa mutatja a helyesen felidézett szavak arányát a különböző tanulmányozási feltételek esetén; az ezen végzett variancianalízis a tanulmányozási feltételek fóhatását mutatja: $\mathrm{F}(4,44)=5,83, \mathrm{p}<0,001$. A t-próba azt jelezte, hogy ennek a csoportnak az eredménymintázatai nagyon hasonlóak voltak a kevésbé folyékonyan beszélőkéhez.

\section{Töredékkiegészités}

1. Kevésbé folyékonyan beszélő csoport

A töredékkiegészítési feladat eredményeit a 3. táblázat negyedik oszlopa mutatja. A tanulmányozott és az új, nem tanulmányozott tételeken végzett globális varianciaanalízis a feltételek főhatását mutatta, $\mathrm{F}(5,55)=7, \mathrm{p}<0,001$.

Az előzőleg nem látott szavak töredékkiegészítési aránya 0,55 volt. Egy szó kétszeri elolvasása románul $(, 46)$, valamint ennek az elképzelése $(0,66)$ nem eredményezett a töredékkiegészítési teljesítményben statisztikailag szignifikáns javulást. A töredékkiegészítési arányok az olvasd románul és képzeld el feltételek esetén nem különböztek szignifikánsan a nem tanulmányozott szavakétól, így megismételve WATKins és PEYNiRCioglu eredményeit (1983). Érdekes viszont, hogy enyhén szignifikáns különbséget találtam az olvasd románul és a képzeld el feltételek között, $\mathrm{t}=1,63, \mathrm{p}=0,1$.

A fennmaradó három feltétel (olvasd angolul, olvasd románul és angolul, fordítsd le) nem különbözött szignifikánsan egymástól: $\mathrm{t}=0,64, \mathrm{t}=0,65$, illetve $\mathrm{t}=0,71$. Tekintetbe véve, hogy úgy tartják, hogy a töredékkiegészítés a tanulmányozás és teszt nyelvének összehangolásától függ, mindez nem meglepő. Az viszont meglepő, hogy nem találtam szignifikáns különbséget a képzeld el feltétel és az előbb említett három feltétel között. Ez azt bizonyítja, hogy feltevésemmel ellentétben a töredékkiegészítés szintén javul az elaboratív feldolgozással. Csak a nem tanulmányozott szavak és a fordítsd le feltétel között volt egy kicsit szignifikáns különbség, $\mathrm{t}=1,33, \mathrm{p}=0,1$, ami aláhúzza, hogy a töredékkiegészítés nem teljesen adatvezérelt. 
2. Folyékonyabban beszélő csoport

A helyesen kiegészített szavak arányát a 4. táblázat negyedik oszlopa mutatja. Az öt tanulmányozási feltétel töredékkiegészítési arányán és az új tételeken végzett varianciaanalízis nem mutatott szignifikáns főhatást. Annak érdekében, hogy felmérjem az előzőleg tanulmányozott és előzőleg nem tanulmányozott szavak közötti különbséget, a t-próbát használtam. Enyhén szignifikáns különbséget találtam az olvasd angolul feltétel, az olvasd románul és angolul feltétel, a fordítsd le, a képzeld el és a nem tanulmányozott szavak között. Mindez ismét bizonyítja, hogy az előfeszítést nem csak egy tétel vizuális bemutatása befolyásolja, hanem a konceptuális kidolgozás is.

\section{Igen/nem felismerés és kapcsolata a másik két feladattal}

1. Kevésbé folyékonyan beszélő csoport

A 3. táblázat harmadik oszlopában jelennek meg ennek a feladatnak az eredményei. A tanulmányozási feltételek fóhatását mutatta a helyes találatokon végzett variancianalízis: $\mathrm{F}(4,44)=2,65, \mathrm{p}<0,05$. Ennek ellenére a t-próba segítségével kimutattam, hogy a felismerési arány az olvasd románul $(0,23)$ és az olvasd angolul $(0,72)$ feltételek esetén különbözik egymástól, az utóbbi feltétel pedig a leghatékonyabb az összes közül. A képzeld el feltétel $(0,46)$ szignifikánsan jobb felismerési teljesítményt eredményezett, mint az olvasd románul feltétel, $\mathrm{t}=2,28$, $\mathrm{p}<0,05$. A szavak lefordítása $(0,64)$, valamint a román és angol nyelven való olvasása $(0,7)$ szignifikánsan jobb felismerési teljesítményt eredményezett, összehasonlítva egy szó kétszeri román olvasásával: $\mathrm{t}=2,03, \mathrm{p}<0,001$, illetve $\mathrm{t}=1,59$, $\mathrm{p}<0,001$. Enyhén szignifikáns különbséget találtam az olvasd románul és angolul, fordítsd le és a képzeld el feltételek között; $\mathrm{t}=1,93, \mathrm{p}<0,1$, illetve $\mathrm{t}=1,59$, $\mathrm{p}<0,1$.

A töredékkiegészítési feladatban csak az serkentette a teljesítményt, ha a személyek egy szót angolul tanulmányoztak. A román nyelven való tanulmányozás nem javította a helyesen kiegészített szavak számát, habár a képzeld el feltétel esetén a teljesítmény egy picivel jobb volt, mint az olvasd románul feltétel esetén $(\mathrm{t}=1,63, \mathrm{p}=0,1)$. Ezzel ellentétben, a felismerési próbánál - mindamellett, hogy a tanulmányozás nyelve fontos volt - a szavakon végzett feldolgozás típusa is befolyásolta a felismerési emlékezetet. Például, annak ellenére, hogy a személyek mind az olvasd románul, mind a képzeld el feltételek során románul tanulmányozták a szavakat, a teljesítmény jobb volt az utóbbi feltétel esetén: $\mathrm{t}=2,28, \mathrm{p}<$ 0,05 . Ezek az eredmények azt jelzik, hogy összehasonlítva a felismerési feladattal, a töredékkiegészítési próbának egy kissé erősebb fogalmilag vezérelt összetevője van, viszont az én hipotézisemmel ellentétben mindkét feladat fogalmilag vezérelt.

Másrészt a felismerési próba eredménymintázatai is különböztek a szabad felidézés eredményeitől a felismerési folyamatban található adatvezérelt összetevőt tükrözve. Az olvasd románul és angolul feltétel szignifikánsan jobb felismerést eredményezett, mint a képzeld el feltétel, $\mathrm{t}=1,93, \mathrm{p}<0,1$, ami feltehetőleg leg- 
alább akkora elaborációt igényelt, mint amennyit megítélnénk neki a szabad felidézéses teljesítmény alapján. A képzeld el feltétel esetén a személyek csak látták a szavakat románul, ami valószínűleg kellemetlenül érintette őket az angolul folyó felismeréses próba végzésekor, a felismerés adatvezérelt aspektusából kifolyólag. A szabad felidézési feladat esetében szignifikáns különbséget találtam a képzeld el és olvasd románul és angolul feltételek között, mint ahogy a felismerési próba esetén is. Ez azt mutatja, hogy az utóbbi feladatnak van egy fogalmilag vezérelt komponense is. A szabad felidézés során megfigyelt enyhe haszon a szavak románul való tanulmányozása esetén, a szavak angolul való tanulmányozásához képest, fordított volt a felismerési feladat esetén: ekkor jobb volt a teljesítmény, ha a személyek angolul olvasták a szavakat és nem románul. Ismét a tanulmányozás és teszt nyelvének összehangolása segíti a teljesítést a felismerési feladat esetében, ennek adatvezérelt komponensét tükrözve. Összegezve, a felismerési feladatnak van adatvezérelt és fogalmilag vezérelt komponense is: mind a tétel formája, mind a fogalmi elaboráció befolyásolja a felismerési teljesítményt.

\section{Folyékonyabban beszélők csoportja}

A 4. táblázat harmadik oszlopa tartalmazza az öt tanulmányozási feltétel helyes találatainak arányát, valamint a hamis riasztás arányát. A tanulmányozási feltételek főhatása nem volt szignifikáns, ahogy a helyes találatok arányán végzett varianciaanalízis mutatta. Ahogy a hamis riasztás arány mutatja, mind az öt feltétel esetén a teljesítmény jobb volt, mint ahogy az a véletlen alapján lenne. Az olvasd románul feltétel szignifikánsan rosszabb teljesítményt eredményezett, összehasonlítva az összes többi feltétellel (kivéve persze a nem tanulmányozott szavakat). Azt a következtetést vonhatjuk le tehát, hogy a folyékonyabban beszélő háromnyelvủek fogalmilag közvetítik harmadik nyelvüket is.

\section{AZ EREDMÉNYEK MEGBESZÉLÉSE}

Kísérletem célja az volt, hogy 1) egyetlen vizsgálatban, azonos elsajátítási stratégiákat és különböző előhívási feladatokat alkalmazva olyan teljesítménymintákat mérjek fel, amelyeket az egyik (nyelvtől való függetlenség vagy függőségi elmélet) vagy a másik (nyelvtől való függés vagy függetlenség elmélet) modell alátámasztására szoktak felhozni; 2) kevésbé folyékonyan beszélő és folyékonyabban beszélő háromnyelvủeket alkalmazva ellenőrizzem a fejlődési hipotézist.

JACOBY (1983), ROEDiger és BLAXTON (1987b), valamint DuRdunOglu és ROEDIGER (1987) általános keretmunkáját használva azt feltételeztem, hogy az angolt kevésbé folyékonyan beszélők teljesítménye egy adatvezérlésű töredékkiegészítési feladat esetében a elsajátítás és az előhívás alatt használt nyelv egybeesésétől kell függjön, a függetlenség elméletét támasztva alá; a fogalmilag vezérelt szabad felidézés, hipotézisemnek megfelelően nem függ annyira a tanulmányozás nyelvétől, a nyelvtől való függetlenség hipotézisének megfelelően; a felismerés esetében a két mintázat keverékét feltételeztem. Az angolt folyékonyabban beszélő csoportra a hipotézisem az volt, hogy nem fogok a különböző tanulmányozási 
feltételek között szignifikáns különbséget találni, így bizonyítékot nyerve a fejlődési hipotézis, valamint KROLL és STEWART modellje (1994) mellett.

Kísérletem eredményei részben alátámasztották feltételezéseimet: a szabad felidézés eredményei a kevésbé folyékonyan beszélők esetében a nyelvtől való függetlenség elméletet húzták alá: a tanulmányozás nyelvének kis szerepe volt, viszont a mélyreható feldolgozás nagy hatással volt az eredményekre. A szavak kétszeri elolvasása román vagy angol nyelven nem befolyásolta felidézésüket szignifikáns mértékben, viszont amikor a személyeknek el is kellett képzelniük az illető szót, a helyesen felidézett szavak száma szignifikánsan megnőtt. Az eredmények hasonló javulása volt tapasztalható, amikor aktívan generálni kellett a fordítást, vagy amikor egy szót mindkét nyelven olvastak tömeges bemutatással (elsajátítási változatosság). Meglepő, hogy a folyékonyabban beszélő személyek ezen feladat esetében majdnem azonos eredménymintázatot produkáltak. Az a tény, hogy szignifikáns különbségek voltak a különböző tanulmányozási feltételek között azt mutatja, hogy ez a feladat nagymértékben fogalmilag vezérelt. Ez igaz a gyakorlottsági szinttől függetlenül.

Azt mondhatnánk, hogy a szabad felidézés eredményei nyelvtől való függőséget mutatnak, mivel az olvasd angolul és románul feltétel esetén nyert teljesítmény szignifikánsan meghaladta mind az olvasd angolul, mind az olvasd románul feltétel esetén nyert teljesítményt. Én viszont ezt nem a kettős kódolásnak, hanem a többletfeldolgozásnak tulajdonítom, ami a tömeges tételek másodszori bemutatásakor történt, amikor is a felszíni forma megváltozott (például JACOBY, 1978). GLANZER és DUARTE (1971) kimutatták, hogy ez a hatás eltűnik a ritkított bemutatással (lásd még Kolers, 1966; Kolers, GonZales, 1980; Paivio, Clark, LAMBerT, 1988). Dellarosa és Bourne (1985) arra kérték személyeiket, hogy mondatokat tanulmányozzanak; ezeket a mondatokat különböző idóközönként megismételték, és ugyanabban vagy más formában mutatták be (auditíven vagy vizuálisan, ugyanazon személy hangján vagy más személy hangján). Amikor a mondat pontosan ugyanúgy volt megismételve, az elosztási, elhelyezési (spacing) hatás normális volt, amikor viszont megváltoztatták a felszíni formát a tömeges bemutatás esetén, a teljesítmény nagymértékben javult, annyira, hogy ez a hatás teljesen eltűnt (2. kísérlet) vagy nagymértékben csökkent (1. kísérlet). Természetesen nem javasoltak két különálló kódot, egyet az auditíven, egyet meg a vizuálisan bemutatott mondatok részére, vagy egyet-egyet a két különböző hangnak; a javulást annak a többletfeldolgozásnak tulajdonították, ami a második bemutatáskor a megváltozott formára lépett fel. Ugyanez az értelmezés vonatkozik az én eredményeimre is: ha megismételtem volna a fogalmakat más nyelven egy bizonyos késedelemmel, a teljesítmény valószínủleg nyelvtől való függetlenséget mutatott volna, megismételve mások eredményeit (például GLANZER, DUARTE, 1971).

A töredékkiegészítési feladat esetén (kevésbé folyékonyan beszélők csoportja) a fontos változó a bemutatás nyelve volt: ha ez megegyezett a feladat nyelvével (angol), akkor a helyesen kiegészített szavak aránya nagyobb volt a nem tanulmányozott szavakéhoz képest. Ha a bemutatás román nyelven történt, a helyesen kiegészített szavak aránya kisebb volt, mint az előzőleg nem látott szavaké. Mindemellett, a fokozott elaboratív feldolgozás is befolyásolta az eredményeket: enyhén 
szignifikáns különbség volt az olvasd románul és képzeld el feltételek között, és nem találtam szignifikáns különbséget a képzeld el feltétel és azon három feltétel között, ami feltételezte a szó angol nyelvű változatának tanulmányozását. Ehhez járul még az is, hogy csak a nem tanulmányozott szavak és a fordítsd le feltétel között volt az eredmény enyhén szignifikáns, ami aláhúzza azt, hogy a töredékkiegészítési feladat nem csak adatvezérelt. A legjobb teljesítményt a fordítsd le feltétel esetén figyeltem meg, ahogy az a felismerési feladat esetén kellett volna legyen. Összegezve, a töredékkiegészítés mind a bemutatás nyelvétől, mind a tanulmányozás során használt elsajátítási művelettől függ, így az adatvezérelt és fogalmilag vezérelt folyamatok kombinációját mutatva a háromnyelvűek memóriájában.

A folyékonyabban beszélő csoport eredményei megerősítették a fenti megállapítást: egyformán jól teljesítettek minden elsajátítási feltétel esetén és a legjobb eredményeket a fordítsd le feltétel esetén érték el, akár a kevésbé folyékonyan beszélő csoport. Az a tény, hogy nem találtam szignifikáns különbségeket a különböző feltételek között, arra a következtetésre juttat, hogy a fejlődési hipotézis érvényes egy kis módosítással: a kevésbé folyékonyan beszélő háromnyelvűekre a lexikális és fogalmi közvetítés kombinációja jellemző, viszont a folyékonyabban beszélő háromnyelvűek teljesítményét kizárólagosan a fogalmi közvetítés jellemzi. Érdekes lenne olyan tanító foglalkozásokat végezni, mint amilyeneket CHEN (1990) végzett, hogy lássuk, milyen korán érhető tetten a fogalmi közvetítés mintázata a harmadik nyelv elsajátításában.

Végül, a felismerési próbánál, a kevésbé folyékonyan beszélő csoport esetén mind a bemutatás nyelve, mind a tanulmányozás során használt elsajátítási műveletek befolyásolták a teljesítményt. Például egy szó angol nyelven való tanulmányozása (összehangolás a feladat nyelvének felszíni jellemzőivel) kedvező hatással volt a teljesítményre, viszont ugyanilyen jó hatása volt a képzeld el feltételnek is. A legjobb teljesítményt akkor figyeltem meg, amikor mind az adatvezérelt, mind a fogalmilag vezérelt folyamatok alkalmazva voltak, mint amilyen a fordítsd le feltétel; ebben az esetben az elsajátítás és a feladat nyelve megegyezett, így beindítva a felismerési feladat adatvezérelt komponensét. Az eredmények azt is mutatták, hogy ennek a feladatnak egy kicsit erősebb fogalmilag vezérelt összetevője van, mint a töredékkiegészítésnek.

A folyékonyabban beszélő személyek a különböző tanulmányozási feltételek során egy általános eredménymintázatot mutattak. Tehát azt a következtetést lehet levonni, hogy amikor az egyének elérnek egy bizonyos gyakorlottsági szintet a harmadik nyelvük terén, akkor teljes mértékben fogalmilag közvetítik ezt.

\section{KÖVETKEZTETÉSEK}

Az a tény, hogy egyetlen kísérletben, azonos elsajátítási feltételek mellett, de különböző emlékezeti feladatokat alkalmazva mind nyelvtől független, mint nyelvtől függő mintázatokat találtam, azt vonja maga után, hogy a két- és háromnyelvűek reprezentációjának a kérdését nem oldhatjuk meg anélkül, hogy egy olyan mo- 
dellt alkossunk, amely magába foglalja nemcsak a tárolási folyamatokat, hanem az előhívási folyamatokat is (ANDERSON, 1978). Valószínű, hogy azok a feladatok, amelyek a háromnyelvủek emlékezeti rendszerében levő képzetekkel dolgoznak, a feladat előhívási követelményeitől függően különböző eredménymintázatokat vonnak maguk után.

Aláhúznám, hogy a kísérleti személyek nem ismerték az elsajátítás után következő feladat típusát és mindegyikük ugyanazoknak az elsajátítási feltételeknek volt alávetve. Ennélfogva a feladatok eredményei közötti különbségek nem tulajdoníthatók a különböző elsajátítási vagy tárolási stratégiáknak.

Annak ellenére, hogy a személyek feltehetőleg ugyanolyan típusú képzeteket alkottak a tanulmányozott szavakról mindegyik feltétel esetén, az eredmények a nyelvtől független képzetekre és a nyelvtől való függőség és függetlenség keverékére szolgáltattak bizonyítékot. Ennélfogva a képzet típusa nem tárgyalható külön a képzet elérésének eszközétől (KOLERS, BRISON, 1984). Így az a kérdés, hogy a két-, három- vagy többnyelvűeknek közös, fogalmi, nyelvtől független képzeteik vannak a különböző nyelvű szavaikra vagy másfajta reprezentációik, nem eldönthető (GLUCKSBERG, 1984). Ahogy Glucksberg összegezte a problémát: „,akármilyen formája is lesz az emberi fogalmi működés legutolsó modelljének, fontos lesz meghatározni a feltételeket, amelyek mellett a teljesítmény modalitástól független,... illetve ...modalitástól függő, specifikus lesz” $(1984,104)$. Én azt sugallom, hogy az elsődleges változók, amiket meg kell határozni a soknyelvűek memóriájában, ha a nyelvtől való függetlenséget vagy nyelvspecifikusságot akarjuk fontolóra venni, a feladat követelményei.

Az idegen nyelvek fogalmi közvetítését illetően eredményeim a függőségi elméletet támasztják alá, KROLL és STEwART (1994) modelljét. A többnyelvűek mentális rendszerében a szavak az értelem mentén szerveződnek, és nem a nyelv alapján. Mégis, a nyelvelsajátítás nagyon korai szakaszában nyelvspecifikus jelzőingerek is közbeszólnak, még akkor is, amikor a személyek az értelemre koncentrálnak.

A fejlődési hipotézist illetően azt a következtetést vonhatom le, hogy a kevésbé folyékonyan beszélő háromnyelvűek a lexikai szótársításokra is támaszkodnak, de a fogalmi közvetítést is használják. Hogyha bizonyítást nyerne, hogy az idegen nyelv elsajátításának egy nagyon korai szakaszában az egyének csak lexikailag közvetítik ezt a nyelvet, akkor a fejlődési hipotézis teljes mértékben érvényes lenne. Az eddigi eredményeket figyelembe véve, főként CHEN kísérleteit, fel kell tennünk azt a kérdést, hogy létezik egyáltalán egy olyan periódus, amikor az idegen nyelvet tanulni kezdők csak a lexikai asszociációkra támaszkodnak?

A kísérletemben megnyilvánuló eredménymintázatok egy általánosabb dolgot is feltárnak. Kölcsönös interakciót mutattam ki az elsajátítási feltételek és három különböző előhívási tesztforma között; ezt a mintázatot úgy tekintik, mint ami felfed bizonyos, az előhívási teljesítmények közötti disszociációkat. Számos jelenlegi, az emlékezést vizsgáló munka irányul ennek a jelenségnek a megértésére. A teljesítmények közötti disszociációkat bizonyítékként tekintették a széleskörủ kognitív rendszerek elkülönítésére, mint amilyen a procedurális és deklaratív ismeretek megkülönböztetése (például KOLERS, BRISON, 1984) vagy az epizódikus és 
szemantikus memória megkülönböztetése (TULVING, 1983). Ezek a megközelítések azt feltételezik, hogy a disszociációk különleges jelenségek, és magyarázatukra a leghelyesebb megoldás a hipotetikus emlékezeti rendszerek feltalálása. Másrészt viszont, KOLERS és ROEDIGER (1984) úgy gondolták, hogy a megőrzési feltételek közötti disszociációk a különböző típusú elsajátítási műveletek során - ahogy azt ebben és számos más kísérletben találták - nem különleges jelenségek és nem vonják maguk után feltétlenül, hogy magyarázásukra speciális rendszereket találjunk ki. Inkább egy, a kódolási specifikusság elvére támaszkodó megközelítés lenne az az általános elmélet, amely révén megérthetnénk ezeket a disszociációkat. A feladatokon elért teljesítmény olyan mértékben javulna, amennyire az az elsajátítás során alkalmazott folyamatok ismételését követelné meg vagy igényelné.

Ebben a dolgozatban az idegen nyelvet tanulók és a folyékonyabban beszélő háromnyelvúek lexikai és fogalmi emlékezete közötti kapcsolattal foglalkoztam. Annak ellenére, hogy ennek a kérdésnek az elméleti oldala kezdeti fázisban van, véleményem szerint ígéretet tartalmaz egy olyan keret kidolgozására nézve, amelyben a kontextuson kívüli kétnyelvủ feladatokon (fordítás, képmegnevezés és egyetlen szó előfeszítése) elért teljesítmény kapcsolatba hozható a nyelvileg összetett, és az idegen nyelvek használatára inkább jellemző kontextuson belüli teljesítménnyel. A jövőben ezt a perspektívát szeretném körüljárni.

\section{IRODALOM}

ANDERSON, J. R. (1978) Arguments concerning representation for mental imagery. Psychological Review, 85, 249-277.

Anderson, J. R., Bower, G. H. (1973) Human associative memory. Wiley, New York

BLAXTON, T. A. (1985) Investigating dissociations among memory measures: Support for a transfer appropriate processing framework. Unpublished doctoral dissertation, Purdue University

Chen, H.-C. (1990) Lexical processing in a nonnative language: Effects of language proficiency and learning strategy. Memory and Cognition, 18, 279-288.

Chen, H.-C., Leung, Y-S. (1989) Patterns of lexical processing in a nonnative language. Journal of Experimental Psychology: Learning, Memory \& Cognition, 15, 316-325.

Cristoffanini, P., Kirsner, K., Milech, D. (1986) Bilingual lexical representation: the status of Spanish-English cognates. The Quarterly Journal of Experimental Psychology, 38A, 367-393.

DAlrymple-Alford, E. C., AAmiry, A. (1969) Language and category clustering in bilingual free recall. Journal of Verbal Learning and Verbal Behavior, 8, 762-768.

De Groot, A. M. B. (1992a) Determinants of word translation. Journal of Experimental Psychology: Learning, Memory and Cognition, 18, 1001-1018.

DE Groot, A. M. B. (1992b) Bilingual lexical representation: A closer look at conceptual representations. In Frost, R., Katz, L. (eds) Ortography, phonology, morphology, and meaning. Elsevier, Amsterdam, 389-412.

DE Groot, A. M. B. (1993) Word-type effect in bilingual processing tasks: Support for a mixed represetnation system. In Schreuder, R., Weltens, B. (eds) The bilingual lexicon. John Benjamins, Amsterdam, 27-51. 
De Groot, A. M. B., Dannenburg, L., Van Hell, J. G. (1994) Forward and backward word translation. Journal of Memory and Language, 33, 600-629.

Dellarosa, D., Bourne, L. E. (1985) Surface form and the spacing effect. Memory and Cognition, 13, 529-537.

Dufour, R., Kroll, J. F. (1995) Matching words to concepts in two languages: A test of the concept mediation model of bilingual representation. Memory and Cognition, 23, 166180 .

Durdunoglu, A. Y., Roediger, H. L. (1987) Test differences in accessing bilingual memory. Journal of Memory and Language, 26, 377-391.

ERvin, S. M., OsGOOD, C. E. (1954) Second language learning and bilingualism. Journal of Abnormal Social Psychology, Supplement, 139-146.

Fischler, I., BoAz, T., Weidner, J. M., Ransdell, S. (1986) An ERP analysis of repetition priming in bilinguals. Paper presented at the Eight International congress on Evoked Potentials. Palo Alto

Glanzer, M., Duarte, A. (1971) Repetition between and within languages in free recall. Journal of Verbal Learning and Verbal Behavior, 10, 625-630.

GLucksberG, S. (1984) The functional equivalence of common and multiple codes. Journal of Verbal Learning and Verbal Behavior, 23, 100-104.

GrosjeAn, F. (1982) Life with two languages: An Introduction to Bilingualism. Harvard University Press, Cambridge

HakutA, K. (1987) Degree of bilingualism and cognitive ability in Mainland Puerto Rican children. Child Development, 58, 1372-1388.

JАСОву, L. L. (1978) On interpreting the effects of repetition: Solving a problem versus remembering a solution. Journal of Verbal Learning and Verbal Behavior, 17, 649-667.

JАСОву, L. L. (1983) Remembering the data analyzing the interactive processes in reading. Journal of Verbal Learning and Verbal Behavior, 22, 485-508.

JACOBy, L. L., DALlas, M. (1981) On the relationship between autobiographical memory and perceptual learning. Journal of Experimental Psychology: General, 3, 306-340.

JAROVinskiJ, A. (1997) The structure of the mental lexicon in Hungarian-Russian bilingual children. Acta Linguistica Hungarica, 44 (1-2), 203-223.

Johnson, J. S., NewPORT, E. L. (1989) Critical period effects in second language learning: The influence of maturational state on the acquisition of English as a second language. Cognitive Psychology, 21, 60-99.

Johnston, W. H., DARk, V. J., JaCOBy, L. (1985) Perceptual fluency and recognition judgements. Journal of Experimental Psychology: Learning, Memory and Cognition, 11, 3-11.

Kirsner, K., Brown, H. L., Abrol, S., Chadha, N. K., Sharma, N. K. (1980) Bilingualism and lexical representation. Quaterly Journal of Experimental Psychology, 32, 585-594.

Kirsner, K., Smith, M. C., Lockhardt, R. S., King, M. L., Jain, M. (1984) The bilingual lexicon: Language-specific units in an integrated network. Journal of Verbal Learning and Verbal Behavior, 23, 519-539.

Kolers, P. A. (1963) Interlingual word associations. Journal of Verbal Learning and Verbal Behavior, 2, 291-300.

KOlERS, P. A. (1966) Interlingual facilitation of short-term memory. Journal of Verbal Learning and Verbal Behavior, 5, 314-319. 
Kolers, P. A., Brison, S. J. (1984) Commentary: On pictures, words, and their mental representation. Journal of Verbal Learning and Verbal Behavior, 23, 105-113.

Kolers, P. A., GONZALEs, E. (1980) Memory for words, synonyms and translations. Journal of Experimental Psychology: Human Learning and Memory, 6, 53-65.

Kolers, P. A., Roediger, H. L. (1984) Procedures of mind. Journal of Verbal Learning and Verbal Behavior, 23, 425-449.

Kroll, J. F., Curley, J. (1988) Lexical memory in novice bilinguals: The role of concepts in retrieving second language words. In Gruneberg, M., Morris, P., Sykes, R. (eds) Practical aspects of memory, 2. John Wiley \& Sons, London, 389-395.

Kroll, J. F., Stewart, E. (1990) Concept mediation in bilingual translation. Paper presented at the 31 st Annual Meeting of the Psychonomic Society, New Orleans

Kroll, J. F. STEwart, E. (1994) Category interference in translation and picture naming: Evidence for asymmetric connections between bilingual memory representations. Journal of Memory and Language, 33, 149-174.

Lambert, W. E., Ignatow, M., Krauthamer, M. (1968) Bilingual organization in free recall. Journal of Verbal Learning and Verbal Behavior, 23, 425-449.

MADIGAN, S. A. (1969) Intraserial repetition and coding processes in free recall. Journal of Verbal Learning and Verbal Behavior, 8, 825-835.

MAndler, G. (1980) Recognizing: The Judgement of previous occurrence. Psychological Review, 87, 252-271.

MORTON, J. (1990) A lexikon felbontása: Információfeldolgozás szempontú megközelítés. In Kónya A. (szerk.) Az emberi emlékezet pszichológiai elméletei. Tankönyvkiadó Budapest, 213-238.

PAivio, A. (1969) Mental imagery in associative learning and memory. Psychological Review, $76,241-263$.

Paivio, A., Clark, J. M., LAmbert, W. E. (1988) Bilingual dual coding theory and semantic repetition effects on recall. Journal of Experimental Psychology: Learning, Memory and Cognition, 14, 163-172.

Paivio, A., Desrochers, A. (1980) A dual-coding approach to bilingual memory. Canadian Journal of Psychology, 34, 388-399.

Paivio, A., Yuille, J. C., Madigan, S. A. (1968) Concreteness, imagery, and meaningfulness values for 925 nouns. Journal of Experimental Psychology Monograph, 76 (1, Pt. 2)

POTTER, M. C. (1979) Mundane symbolism: The relations among objects, names, and ideas. In Smith, N. R., Franklin, M. B. (eds) Symbolic functioning in childhood, Erlbaum, Hillsdale, 41-65.

Potter, M. C., So, K.-F., von Eckhardt, B., Feldman, L. B. (1984) Lexical and conceptual representation in beginning and more proficient bilinguals. Journal of Verbal Learning and Verbal Behaviour, 23, 23-38.

Radu, I., Miclea, M., Albu, M., Moldovan, O., Nemes, S., Szamoskozi, St., (1993) Metodologie psihologica si analiza datelor. Sincron, Cluj-Napoca

Roediger, H. L., Blaxton, T. A. (1987a) Effects of altering surface features on priming in word fragment completion. Memory and Cognition, 14, 178-192.

Roediger, H. L., Blaxton, T. A. (1987b) Retrieval modes produce dissociations in memory for surface information. In Gorfein, D. S., Hoffman, R. R. (eds) Memory and cognitive processes. The Ebbinghaus Centennial Conference. Erlbaum, Hillsdale 
Scarborough, D. L., Gerard, L., Cortese, C. (1984) Independence of lexical access in bilingual word recognition. Journal of Verbal Learninng and Verbal Behavior, 23, 84-99.

SCHWANENFlugel, P. J., REY, M. (1986) Interlingual semantic facilitation: Evidence for a common representational system in the bilingual. Journal of Memory and Language, 25, $605-618$.

SEgalowitz, N. S. (1986) Skilled reading in the second language. In Vaid, J. (ed.) Language Processing in Bilinguals: Psycholinguistic and Neuropsychological Perspectives, Lawrence Erlbaum, Hillsdale, 238-254.

Sholl, A., Sankaranarayanan, A., Kroll, J. F. (1995) Transfer between picture naming and translation: A test of asymmetries in bilingual memory. Psychological Science, 6, 4549.

SnOdGrass, J. G. (1980) Towards a model for picture - Word processing. In Kolers, P. A., Wrolstad, M. E., Bouma, H. (eds) Processing of visible language, Plenum, Vol. 2, New York, 565-584.

SNODGrass, J. G. (1984) Concepts and their surface representation. Journal of Verbal Learning and Verbal Behavior, 23, 3-22.

SNODGRASs, J. G., VANDERwarT, M. A. (1980) A standardized set of 260 pictures: Norms for name agreement, image agreement, familiarity and visual complexity. Journal of Experimental Psychology: Human Learning and Memory, 6, 174-215.

Thuma, O., PléH, Cs. (1995) Lexikális előfeszítés a mentális lexikonban az anyanyelv és egy tanult második nyelv között. Magyar Pszichológiai Szemle, 5-6, 293-304.

Tulving, E. (1983) Elements of episodic memory. Oxford University Press, New York

Tulving, E., Schachter, D. L., Stark, H. A. (1982) Priming effects in wor-fragment completion are independent of recognition memory. Journal of Experimental Psychology: Learning, Memory and Cognition, 8, 336-342.

WATKins, M. J., GARDiner, J. M. (1979) An appreciation of generate-recognise theory of recall. Journal of Verbal Learning and Verbal Behaviour, 18, 687-704.

Watkins, M. J., Peynircioglu, Z. F. (1983) On the nature of word recall: Evidence for linguistic specificity. Journal of Verbal Learning and Verbal Behavior, 22, 385-394.

Weinreich, U. (1953) Languages in contact. Findings and problems. Linguistic Circle of New York, New York

Weldon, M. S., Roediger, H. L. (1987) Altering retrieval demands reverses the picture superiority effect. Memory and Cognition, 15, 269-280. 


\title{
A TRANSFER APPROPRIATE APPROACH \\ TO MULTILINGUAL MEMORY
}

\author{
POLONYI, TÜNDE ÉVA
}

Bilinguals' information-representation and -processing is a controversial theme among psycholinguists: According to some researchers bilinguals have cognitive subsystems linked to their known languages, which include the memory stores, as well, but they are functionally independent from each other (independence position). On the other hand, the interdependence position maintain that bilinguals represent words in a supralinguistic code, possibly based on the meanings of the words, that is independent of the language in which the words occurred. According to the developmental hypothesis second language learners start only with lexical associations, but gradually develop direct links between the second language lexicon and concepts.

The aims of my study were: 1) to measure performance patterns, which are usually taken to reflect the one or the other model, in one experiment, using different retrieval tasks under identical encoding conditions; 2) to examine the developmental hypothesis by using less fluent and more fluent trilinguals.

The subjects of my study were Hungarian-Romanian-English trilinguals, divided into two groups. According to my hypothesis, in the case of the less fluently speakers of English, a mostly data-driven task such as word fragment completion would depend on the matching of language at study and test, thus supporting the independence hypothesis. However, my results showed that in the case of this task both the data-driven and conceptually-driven processing is present: not only the language of study was important, but the increasing elaborate processing during study, as well. The results of the free recall task, as predicted, revealed evidence for interdependence effects. Finally, the recognition task showed again the combination of the two kind of processing: data-driven and conceptually-driven processing. The more fluent subjects, in turn, could face all the conditions and all the tasks almost equally well, suggesting that they mediate their languages entirely conceptually. In sum, we can tell that in the mind of the multilingual words are organised on the basis of meaning, not language. At very early stage of language acquisition, however, language specific cues intrude, even when subjects are concentrating upon meaning.

My general conclusion is that the most useful research paradigm would be a transfer appropriate approach, according to which the performance on the retention tasks benefit to the extent to which procedures demanded by the task repeat those employed during encoding.

Key words: $\quad$ trilinguals, memory system, transfer developmental hypothesis, lexical and conceptual mediation 